\title{
New Innovating Processes of Rock Disintegration
}

\author{
Gabriel Wittenberger ${ }^{1, *}$, Erika Škvareková ${ }^{1}$ and Martin Ocilka ${ }^{1}$ \\ ${ }^{1}$ Institute of Earth's resources, Department of Montaneous Sciences, Technical University of Košice, \\ 040 01, Slovak republic
}

\begin{abstract}
Over the past years, deep drilling technology developed quickly. New technologies better quality of drilling work and accelerated the drilling process. At present, $20-25 \%$ are new techniques while $75-80 \%$ drilling methods used worldwide are traditional. Slovakia is quite at the rear of this tendency: our utilization ration shows $95-98 \%$ traditional drilling methods, in comparison to only $2-5 \%$ new ones. Advancement of new deep well boring technologies causes the evolution of new types of drilling sets for deep drilling (depending on applied techniques). Techniques used have a mechanical and physical impact for drilling of rock. Several tests and analyses of disintegration and drilling methods were performed over the last years. The article focuses on a description of the working principle and utilization possibilities.
\end{abstract}

\section{Introduction}

The introduction of rotary drilling, however, was only the beginning of a long series of successful innovations and the progress made during the 20th century in the drilling of oil wells. Some of the most important innovations have helped to increase the efficiency of oil production while also enabling the search for oil deposits. Market characteristics should guarantee work discipline during technological procedures and wise utilization of equipment from both economic and technical points of view Effectiveness of drilling process depends on the selection of technology and drilling techniques. At the present drilling technology restricts the time for drilling itself as quite a lot of time is absorbed by extra operations. In addition, it is necessary not only to stop the rotation of the drill string but also the circulation of the mud $[1,4]$. Because of physical and chemical impact on rock, the new technologies are reaching good drilling results at higher progressive speeds and a shorter time than the conventional rotation drilling. The mentioned advantages of the physical-chemical drilling methods-though still partly under research-are promising for the near future [3].

\footnotetext{
${ }^{*}$ Corresponding author: gabriel.wittenberger@tuke.sk
} 


\section{Materials and Methods}

\subsection{The thermal stress drilling}

Basically, there are two ways of thermal attack on a rock:

a) by heating it up to $400-600{ }^{\circ} \mathrm{C}$ and cooling it down, which would cause thermal stress and rock disintegration;

b) by heating it up to $1000-2000{ }^{\circ} \mathrm{C}$ thus creating conditions for melting or vaporization of rock.

The latter method is more variable as it can be used for both thermal cracking and degradation of rock by a distribution of the supplied energy across a larger area in order to avoid melting. This method, however, has limited use only to low-diameter bores due to its high power requirements. It can be efficiently used for disintegration of hard rock with sheet structure $[5,6]$.

\subsection{Flame drilling}

Flame drilling works in conditions between thermal stress and melting/vaporization of rock. Fuel and oxygen are fed to the combustion chamber at the bottom of well through pipes inside the conventionally rotating drilling pipe (figure 1). The flame which is about 2400 ${ }^{\circ} \mathrm{C}$ hot flashes from the nozzles to the bottom of well at app. $1800 \mathrm{~m} \cdot \mathrm{s}^{-1}$. Water supplied through the third pipe is cooling down the combustion chamber, the nozzles and the burnt bore [6].

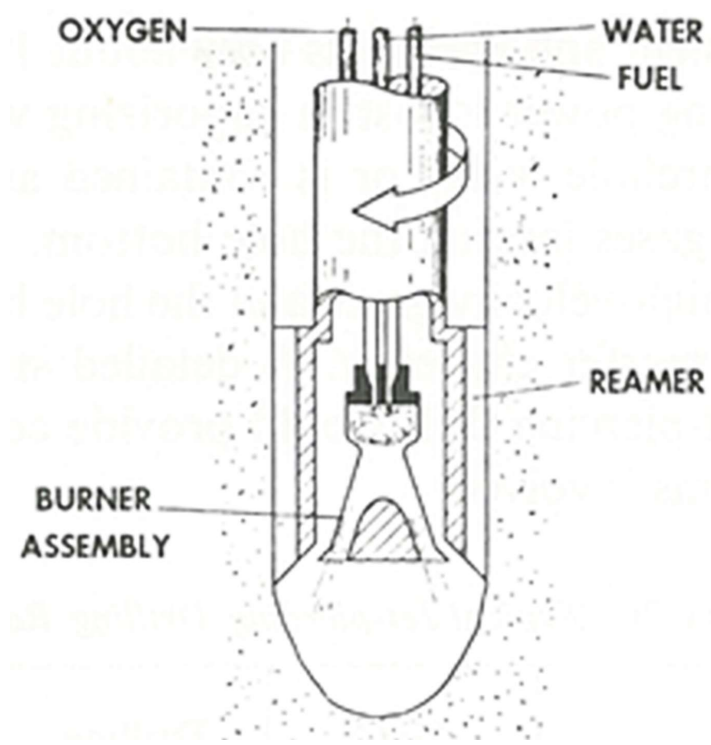

Fig. 1 Flame drilling [6].

Operational characteristics of the drilling are listed in table 1. The tool also includes a mechanical reamer for calibrating of the hole and removal of disintegrated rock [5]. Tests have shown that the maximum drilling progressive speed $v_{p}$ was reached when more $\gg$ rich $«$ oil-oxygen mixture was used $(0,33-0,36)$. The specific volumetric energy for this rock

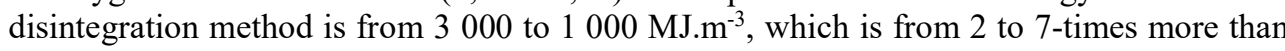
$1500 \mathrm{MJ} . \mathrm{m}^{-3}$ required to heat-up the rock to $400-600{ }^{\circ} \mathrm{C}[6]$. 
Table 1. Flame cutting operational characteristics [6].

\begin{tabular}{|l|l|}
\hline Bore diameter DV $(\mathrm{mm})$ & $160-320$ \\
\hline Drilling progressive speed vp (m.hour-1) & $3-12$ \\
\hline Oxygen consumption mKYS $(\mathrm{l} ; \mathrm{kg} . \mathrm{cm}-2)$ & $28000 ; 10,5$ \\
\hline Oil consumption mOL $(\mathrm{kg} . \mathrm{cm}-2)$ & 7 \\
\hline Oil/water ration & $0.355 \mathrm{~kg} .1 \mathrm{~kg}$ \\
\hline Water consumption $\mathrm{mVOD}(\mathrm{kg} . \mathrm{cm}-2)$ & 4.2 \\
\hline Flame temperature tpl $\left({ }^{\circ} \mathrm{C}\right)$ & 2400 \\
\hline Flame speed vpl $(\mathrm{m} . \mathrm{s}-1)$ & 1800 \\
\hline Power P $(\mathrm{kW})$ & $373-746$ \\
\hline
\end{tabular}

A considerable portion of the energy is consumed for heating-up of walls, thermal and kinetic the energy of gases escaping from the well. The only smaller portion of the energy is transferred to the good face, especially due to short contact time of high-speed gases and the rock. Flame cutting uses a relatively cheap energy source. It can be used where fast rock heating is required [6].

\subsection{Enhanced flame drilling}

Drilling technique and the toll itself are basically identical to the above-described tool. The difference is that instead of oxygen, nitric acid is used as an oxidizing agent. This results in a faster reaction, higher power and app. four-times higher progressive speed (table 2). The author Shapir [7] used enhanced flame drilling with the fuel ratio (oil/ nitric acid) 1: 4,15. The specific volumetric energy $w$ of this enhanced flame drilling was lower by $30 \%$ which indicates that the nitric acid flame transfers the heat to rock more efficiently than the oxygen one. It is probably caused by the flame temperature. Total power transferred to rock was $447 \mathrm{~kW}[5,6]$.

Table 2. Comparison of flame drilling and enhanced flame drilling [6].

\begin{tabular}{|l|c|c|}
\hline & Flame & Enhanced flame \\
\hline Bore diameter DV (mm) & 180 & 280 \\
\hline Progressive speed vp (m.hour-1) & 5 & 18 \\
\hline Specific energy w (MJ.m-3) & 23000 & 16700 \\
\hline $\begin{array}{l}\text { Combustion chamber pressure pSK } \\
(\mathrm{MPa})\end{array}$ & $0.5-0.7$ & 3 \\
\hline & Flame & Enhanced flame \\
\hline Fuel consumption mPAL (g.s-1) & 37 & 140 \\
\hline Fuel consumption mPAL (l.hour-1) & 140 & 530 \\
\hline Oxygen consumption mVZD (g.s-1) & 103 & - \\
\hline Acid consumption mKYS (g.s-1) & - & 610 \\
\hline Water consumption mVOD (g.s-1) & 900 & 950 \\
\hline
\end{tabular}

The data from enhanced flame drilling in silica iron are described in table 3. Using of drill liquid will decrease the maximum progress speed $v_{p}$ from $18-25 \mathrm{~m}$. hour ${ }^{-1}$ (well diameter $27-35 \mathrm{~cm}$ ) to $6,5 \mathrm{~m} /$ hour $^{-1}$. This means that flame cutting is not suitable if the well is filled with drill liquid [5]. 
Table 3. Progress speed of enhanced flame drilling of silica iron $[5,6]$.

\begin{tabular}{|c|c|c|c|c|c|}
\hline $\begin{array}{c}\text { Bore } \\
\mathbf{n r} .\end{array}$ & $\begin{array}{c}\text { Well } \\
\text { length } \\
\mathbf{L}(\mathbf{m})\end{array}$ & $\begin{array}{c}\text { Maximum drilling } \\
\text { speed } \\
\text { vmax (m.hour-1) }\end{array}$ & $\begin{array}{c}\text { Average drilling } \\
\text { speed } \\
\text { vpr (m.hour-1) }\end{array}$ & $\begin{array}{c}\text { Bore } \\
\text { diameter } \\
\text { Dv (mm) }\end{array}$ & $\begin{array}{c}\text { Specific } \\
\text { volumetric } \\
\text { energy } \\
\text { w (MJ.m-3) }\end{array}$ \\
\hline 1 & 12.0 & 18.0 & 18.0 & 280 & 15500 \\
\hline 2 & 16.0 & 20.0 & 12.5 & 330 & 15900 \\
\hline 3 & 11.5 & 18.0 & 18.0 & 270 & 16300 \\
\hline 4 & 14.5 & 19.0 & 15.0 & 280 & 16300 \\
\hline 5 & 16.5 & 24.5 & 21.5 & 285 & 16300 \\
\hline 6 & 16.0 & 20.0 & 16.0 & 285 & 16600 \\
\hline 7 & 14.0 & 25.0 & 9.3 & 350 & 19700 \\
\hline 8 & 2.0 & 6.5 & 6.5 & 180 & 117000 \\
\hline
\end{tabular}

Individual tests showed that the enhanced flame drilling technique is more efficient than flame drilling. Drilling speed is the key factor why this tool is so interesting, despite the higher price of nitric acid [6].

\subsection{Electrical current drilling}

Electrical current drilling/rock disintegration principle is based on the idea to create thermal stresses which would degrade the rock and thus making conventional drilling easier (figure 2).

Most rocks are semi-conductive. Only metallic minerals/ores have higher conductivity (by several orders), depending on the content of metallic elements. Hence, this disintegration method is used mainly for this type of rocks $[6,8]$.

A current with the frequency $60 \mathrm{~Hz}$ is generated during drilling and transferred to the rock through a sharp bit. The bit rotates with low rpm and the air which circulates through the well is removing the rock fragments while attacking the rock with high temperature $[1,6]$. This creates thermal stresses which crush the rock. Research results are presented in table 4.

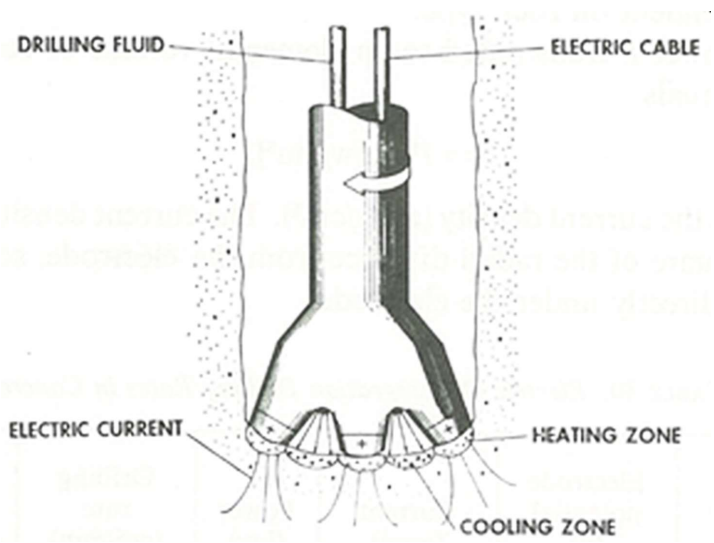

Fig. 2. Electrical current drilling $[5,7]$.

Electrical power attacking the rock is expressed by the relation: 


$$
P=k \cdot \frac{U^{2}}{R} \quad[\mathrm{~W}]
$$

where $\mathrm{k}-\mathrm{a}$ constant specifying type of electrode $(\mathrm{cm})$,

$\mathrm{U}$ - voltage on an electrode $(\mathrm{V})$,

$\mathrm{R}$ - rock resistance $(\Omega)$.

Total progressive speed depends on the type of drilled rock.

Power $P$ transferred to the elementary volume of the rock under the bit can be expressed by the equation:

$$
P=i^{2} \cdot R \quad[\mathrm{~W}]
$$

where $\mathrm{i}$ - current intensity (A).

Table 4. Electrical current drilling operational characteristics [5, 7].

\begin{tabular}{|c|c|}
\hline Bore diameter Dv (mm) & $25-51$ \\
\hline Voltage U (V) & $600-1000$ \\
\hline Current I (A) & $2-10$ \\
\hline Current frequency fp (Hz) & 60 \\
\hline Power P (kW) & $1.2-11$ \\
\hline Power coefficient kv (dim. free) & $0.93-1.06$ \\
\hline Circumferential speed a (rpm) & 90 \\
\hline Bit axial pressure F(A) & 57 \\
\hline Air consumption mVZD (l.min-1) & $8-64$ \\
\hline Progressive speed of drilling vp (cm.min-1) &
\end{tabular}

Applicability of this method in the mining industry is proven by experience from the USA. In one iron-ore deposit, they registered an increase of driving speed from 0,025 to 0,6 m.hour-1 ; in other ore-deposit, it was the increase from 0,2 to 0,9 m.hour- ${ }^{1}$ (they used an autotransformer with the power $100 \mathrm{kWA}$ resp. $60 \mathrm{kWA}$ ).

In addition to this, many tests were made during which the rock was preheated by electrical current to $816^{\circ} \mathrm{C}$ (with simultaneous use of a cutting-type bit). With this temperature, the rock lost practically all its strength [10]. Although the specific volumetric energy $w$ is the same as for conventional rotation drilling, this method can be used for drilling of rock with very good conductivity (e.g. quartz) [6].

\section{Conclusion}

Market characteristics should guarantee work discipline during technological procedures and wise utilization of equipment from both economic and technical points of view.Effectiveness of drilling process depends on the selection of technology and drilling techniques.At the present drilling technology restricts the time for drilling itself as quite a lot of time is absorbed by extra operations. In addition, it is necessary not only to stop the rotation of the drill string but also circulation of the mud [10,11]. 
Because of physical and chemical impact on rock, the new technologies are reaching good drilling results at higher progressive speeds and at a shorter time than the conventional rotation drilling. The mentioned advantages of the physical-chemical drilling methods-though still partly under research-are promising for the near future.

\section{References}

1. P. Bujok, M. Klempa, M. Porzer, R. Rado, P. Pospíšil, JP J. Heat Mass Transfer, 9, 2 (2014)

2. G. Wittenberger, M. Cehlár, Z. Jurkasová, Acta Montan. Slovaca, 17, 4 (2013)

3. P. Bujok, D. Grycz, M. Klempa, A. Kunz, M. Porzer, A. Pytlik, Z. Rozehnal, P. Vojčiňak, Energy, 64, 44 (2014)

4. J. Kačur, M. Laciak, M. Durdán, Proceedings of the 13th International Carpathian Control Konference (Piscataway, Podbanské, 2012)

5. G. Wittenberger, Konvenčné a inovatívne spôsoby vítania-híbenia geotermálnych vrtov zamerané na lokalitu Košickej kotliny a ich možné využitie (TU FBERG, Košice, 2016)

6. W. C. Maurer, Advanced Drilling Techniques (Petroleum Publishing Co., Tulsa, 1980)

7. Ya. I. Shapir, Proc. Of the All-Union Research Inst. For Drilling Techn., 1, 10 (1963)

8. M. Cehlár, Z. Jurkasová, D. Kudelas, R. Tutko, J. Mendel, Adv. Mater. Res., 4, 1001 (2014)

9. I. Leššo, P. Horovčák, P. Flegner, B. Pandula, SGEM 2008 (STEF92 Technology Ltd., Albena, 2008)

10. J. Pinka, G. Wittenberger, J. Engel, Borehole mining (TU FBERG, Košice, 2007)

11. J. Bocan, M. Sidorová, M. Šofranko, Metallurgy 56, 1-2 (2017) 